\section{Ethnicity, National Integrity and Monument in Argal ${ }^{1}$}

\section{Man Bahadur Khattri ${ }^{2}$}

"Monuments may express the new sense of place and time. They may change their meanings from one period to another without necessarily changing their form. It can be adopted, it can be left alone, but unless it is actually destroyed, it is almost impossible to eradicate from human experience" (Bradley, 1993:5).

\begin{abstract}
In Nepal, social inclusion, ethnic identity, positive discrimination and proportional representation being burning issues now. Ethnic identity is a vital element of discussion for social inclusion, positive discrimination and proportional representation. Assertion on ethnic identity, seeks recognition from concerned institutions, practices traditions and advocates their ethnic right on socio-economic and political power. These issues are intrinsically linked to national integration. To be sure, very little attention is paid toward ancestral monuments of the past. Monuments vary by their size, pattern, investment, management, and range of dissemination. Local level monuments have little possibility to attract the attention of people of various places and interest, unless they have becomes extraordinary significance. In order to understand monumentality in wider
\end{abstract}

1 This article is based on fieldwork for My M. Phil. Degree at the University of Bergen, Norway, but views are added. I thank to Dev Raj Dahal for proof Reading.

2 Mr. Man Bahadur Khattri is Assistant Lecturer at the Department of Sociology/Anthropology Mahendra Multiple Campus Baglung. social context, it is very important to look at the village level society. Monument building in Nepal has been linked to culture, history, religion, ethnic identity as well as social system. Argal VDC of Baglung district of Nepal represent with multi-ethnic/caste setting that has high influence over the nature of monument and the rituals performed. In multiethnic setting economic, social, and political activities co-exist, each nourishing the other.

Key Words: Ethnicity, Argali Magars, Intra-ethnic relation, Magars, Monuments, National Integrity, Nepal

\section{Introduction}

This article focuses on ethnicity, national integrity and monuments in Argal. It particularly discusses on monuments and their role in the management of intra-ethnic conflict or co-operation in multi-ethnic society. I argue that monuments are linked to identity, access to resources, power, memories, myths, traditions, history, social status, and inter-ethnic relationship. Nepal is in a transitional stage of ethnic conflict or violence, and new values of national integrity. Major political parties of Nepal are trying to institutionalize ethnic even left parties are transcending rather than class perspective in order to solve various socio-economic problems of people of rural and economically backward strata of the country. Ethnic leaders are advocating ethnic autonomy and self-determination as panacea to all their problems.

Nepal is a small country but highly diverse by ethnic and caste groups and their colorful culture. The government has to meet challenges to guarantee equal rights and justice to every citizen. Furthermore, preserving and promoting cultures, languages, religions, customs, and traditions of the indigenous people of Nepal and to create an opportunity for their equal participation and representation in very aspect of 
national life are major challenges. Ethnic identity assertion has become priority and major concern in Nepal. In order to develop country and people with their identity, it is necessary to identify ourselves as Nepalese first, next the reference to our particular ethnic/caste identity, such as Magar or Chettri. Any ethnic and caste person should enjoy power without any discrimination, if any one requires positive discrimination. Positive discrimination should be arranged on the basis of status of individuals defined by socio-economic position, locality, and political status in the society because caste is not equal to class. The geo-political situation and fragile socioeconomic structure of Nepal has put Nepal in critical light. The patterns of production and traditional way of life have changed Nepal's face. A stable Nepal requires heterogeneity in production. In capitalist society, occupations or the role in production are chosen on the basis of skill, interest, opportunity, access rather than identity. Nepalese society's evolution toward capitalistic mode of production requires extensive web of market networks and the supply of labor from various places, which leads to mobility of the individuals and functional specialization. Present material condition of Nepali society demands local autonomy with all sorts of power, except security, international relations and monetary matters. This is the best way to solve the problem of ethnic conflict and to maintain identity and colorful culture in the country. So far Nepal was under feudal and centralized state. The present challenge is to empower people, maintain national integrity and allow opportunities to bloom hundred flowers in the country.

We have to see the factors causing local level conflict and apply measures to unite people and work for their betterment. Monument building in multiethnic society has been playing such role. I will demonstrate the role of monuments cohesion in multi ethnic and caste society, maintain their identity, resolve conflict and foster co-operation as major factors of social life in Nepal.

\section{People and Place}

Argal VDC lies in central west of Baglung district of Nepal. It is inhabited by various ethnic and caste people. The Magars are the major ethnic group in Argal. They are the third largest group occupying $7.1 \%$ of total population of Nepal. According to the classification of Nepal Federation of Ethnic Nationalities (NEFIN) the Magars are categorized as disadvantaged group. Nepal Magar Sangh (Nepal Magar Association) is the member organization of NEFIN. The Magars are among 59 ethnic groups recognized by the state. The Magars of various sub-clans are highly diverse and scattered through out Nepal. They occupy $27.75 \%$ of total population in Baglung district. According to the Census (2002:47), the Magars in Argal VDC are in dominant position occupying $53.49 \%$ of total population, followed by Chhetries (16.34\%), Ironsmith (11.92\%), Bahun (7.59\%), Tailor (5.70\%), Cobbler (3.81\%), Goldsmith (0.48\%), Sanyasi $(0.40 \%)$, and others $(0.24 \%)$. In this Census, Chatayal are not recorded. The Argali Magars speak Nepali language; however they are learning Magar language as well. According to the Census (2002:144), Mother language speakers are 243 or $18.24 \%$. Regardless of their caste/ethnic identity people are segregated economically and politically. There is no concrete data of poverty on the basis of their identity, but every ethnic/caste people is struggling hard for survival to fulfill their basic needs. Formal education has become part of their social and cultural life.

Argal VDC is situated in a hill area, most of the area is steep and narrow valleys. Most of the areas are covered by forest, which is source of fuel, fodder, fiber, food, medicinal herbs etc. Land is not fertile and it demands heavy compost manure of livestock which is going to be a difficult for the people due 
to the out migration of young people from the village. There are two streams running from Argal. They are utilized for irrigation, micro hydro and water mills. Most of the people regardless ethnic and caste identity are subsistence farmers. There is no conflict in using common resources such as forest, water, grazing land on the basis of ethnic/caste identity. Many young male have migrated to foreign countries for better income. Some educated persons have migrated to the city for education and job opportunities; and some are involved in teaching at local schools. There has been no violent conflict among ethnic groups on the basis of identity. Other caste and ethnic people have accepted the leadership of the Magars of various clans at different time due to their first settlement and their demographic weight.

\section{Monument}

In English the word "monument" is often used in reference to something of extraordinary size and power. The word comes from the Latin "monere," which means 'to remind' or 'to warn' (Wikipedia). Monuments in Nepali language are called smarak, which literally means the establishment of objects in memory of person. Monuments are defined as 'anything enduring that serves to commemorate'. Monuments are about memory; they link the past to the present. The results of commemorative zeal can include everything from gravestones to great temples (Elliott, 1964:52). Generally people consider monument as old and visible structures rather new and memorial grounds which is associated with any ethnic and caste group. "The very notion of a modern monument is a contradiction in terms: if it is a monument, it cannot be modern, and if it is modern, it cannot be a monument" (Mumford 1937 in Elliott, (1964:51). In some societies sacred places remain as monuments in themselves without any construction. The introduction of a monument into the 'natural' environment can signify that the human institutions that created the monument, are taking on the permanence of nature: architecture and nature ideally united as can be exemplified in the use of nature's resources in the monument (Cooney, 1994:35). It is important to look at the pattern of place where monuments are built. Monuments are built on specific places which includes, place of birth, burial ground, specific historical events. Monuments also includes where specific types of material are deposited with specific ritual.

There are no definite norms in building monument in different societies. There are some big or visible or extraordinarily fashioned monuments, but it is not necessarily in all societies. Nayanjot Lahiri (1996) has mentioned that in Ballabgarh in India, monuments range from temples to samadhis (memorials), and are located within and outside the settlement, just as elements of the natural environment were culturally incorporated into the religious world of local communities. He further argued that it is also useful to distinguish the religious arenas of "high culture" from that of "folk culture". The landscape of "high culture" was made of monumental religious structure rooted in Islam and Hinduism, mainly in the form of temples and mosques. The folk tradition was inscribed in more humble village and family shrines, memorial in honor of dead saints/ascetics and women who committed sati, miraculous water/mud and slag (Lahiri, 1996: 247). There are mutually coexisting arenas in the lives of local communities intersected in many ways. These elements of the human and natural landscape were mediated and informed by images, artifacts and cultural elements spread across time and space. The Hindu temples are monuments that can be seen as an image, an idea of divinity, a construction of habitation of gods (Ibid: 247-53). In Argal, Monuments are, as Lahiri mentioned, includes folk culture. There are some Hindu temples especially Goddesses Devi. I consider monuments which are built to serve common people on the memory of their dead ancestors. 
From the perspective of participation, identity and ownership, monuments can be categorized as national, regional and local even to particular sub-clan of a caste/ethnic group to the individual as well. Therefore, it is possible to link identity politics to the monuments. National monuments of Nepal have certainly contributed to development of national identity. National monuments such as Shwoyambhu, Lumbini, Pasupatinath, Manakamana etc are the temples and Stupas. Monuments are also identified on the basis of their belongingness of an ethnic people or groups of different identities. They are marker of historical period as well as explicitly focusing around the contemporary socio-political context.

Ancient sites expose are items of 'heritage', and were implicated during the actual construction of national identities. Heritage should be understood as a process, related to human action and agency, and as an instrument of cultural power in whatever period of time one chooses to examine (Harvey, 2003:474). Most of the monuments have feature of permanence. The economic and material life of the people does determine permanence of monuments. Monuments are often looked upon as association with sacred place to express respect of the sacredness by building permanent constructions.

\subsection{Monument in Argal}

There are three types of monuments in Argal. The first type of monuments includes temples: village temples and ancestral shrines, which are used by a single family or shared by a few neighboring families. The second types of monuments include chautaris (resting places), pokharis (pond), bridge, road or tracks. The third type of monuments includes the religious houses i. e. pati pauwa and daramsala. The last two types of monuments serve public welfare and have public access. In order to build these monuments public is obliged for participation voluntary during construction and maintenance. There is not much quarrel for name as of who initiated building and perform rituals for marking its sustenance. There is no specific system to maintain the history of monument builders but memories are maintained and transmitted generation to generation through oral stories and conversation.

On the basis of the people's participation in the ritual and building monuments, I would like to divide further the first type of monuments into three sub-types such as 1) village shrines, 2) ancestral shrines, and 3) the family shrines. To build village shrines, each and every household in the community participate and contribute the labor and other material expenses. These shrines are accessible to all ethnic and caste groups in order to perform rituals. To build the ancestral shrines only certain sub-clan groups of an ethnic/caste group participate and share the expense. The monuments are used mostly by a particular lineage. The family based shrines are very small in size and they are built by the family members themselves. Generally, the public shrines are the biggest among all shrines; similarly ancestral shrines are bigger than family shrines.

The second categories of monuments are built mostly by a family or combination of two or more families. Especially, the Argali Magars from the same sub-clans bear the ritual expenses. It does not matter who initiates building the monuments and performs rituals. In this case, most of the other ethnic/caste groups living in Argal do not practice sharing ritual expense as Argali Magars. The size of these monuments depends on two major aspects, first the location, and the social settings. Chautaries are built to provide comfortable rest for those who are tired after walking up and down with a load on their back. Trees are planted on 


\section{$110 \mid$ Man Bahadur Khattri}

chautaries to provide shadow in the sun and shelter from rain. These days' chautaries are endangered stage due to road construction near chautarie and People start carrying necessary stuff with trucks and pack animals.

In order to build pokharis three things are needed as basic condition such as 1) a flat land, 2) an access track to the pokhari, and 3) source of water. Since the area is steep and hilly, many places are not suitable for digging a pokhari and collecting water, as it may cause landslides. The size of pond depends on how much water is needed to feed the domestic animals. The main source of water is monsoon rain. To collect water for human beings small and separate ponds are built which are called kuwa(well). Kuwas are smaller in size and maintained cleanliness. Building a path or a track, a suspension bridge is also done together with building chautari and pokhari. The tracks are built where it is difficult to walk, and bridges are built where it is difficulty to cross the river or stream. To build a path, suspension bridges, chautari and pokhari together is expensive. Therefore, it requires larger social network and stronger economic power which shows builder's socio-economic and political power in the society.

The third category of monuments includes religious houses. Those houses are built in the sacred places to provide shelter to the pilgrims. The structure of the house is ordinary, because it is just to provide shelter. Religious houses are also built at the cemetery. Building such monuments involves a single household to a few houses of a sub-clan. In Argal there are two houses built as a monument close to the Kali temple. There is a place called dharamsala, standing as an ancestral ritual house. It has been broken for many years but no one has rebuilt it as the memorial of their ancestors.
Ancestral and family shrines belong to sub-caste/clan of caste/ethnic group. The other monuments are common property and have access to all ethnic/caste groups. Monument building is also associated with religious merits; help the ancestors improve their spiritual life as well as honor and prestige in the society for the monument builders. Most of the monuments are built in public places; if they are private they have public access and no conflict in relation to the monuments which are also linked to public welfare.

\subsection{Monument: Serving the Present and Commemorating the Ancestral Past}

Monument builders have no immediate political and economic advantages except their social status and their inner feeing of betterment in next life. Richard Bradley (1993) suggests that what is really new in the decision to ground the experience of place in deliberate, human constructions, and this involves a different relationship with the natural world. Instead of creating an intellectual structure around the features of the natural topography, monument building is a way of establishing or enhancing the significance of particular locations. Once that has happened, those places enter the consciousness of the people who live and work around them until the landscape as a whole is changed (1993:5). Monuments are not only the places in which human experience is molded in special ways. They are also the embodiment of ideas about the world. As such they can be adapted and changed from one period or area to another (Ibid: 69).

The monuments like chautaris and pokharies came into uses after the end of transhumance herding in Argal, which happened together with all ethnic/caste groups due to forest degradation as well as search for alternative source of living by modern education system as well as foreign employment. In order to avoid population pressure on the land people 


\section{2 | Man Bahadur Khattri}

developed an alternative mechanism to manage the forest i.e. stall fed of the domestic livestock. After livestock became stall fed a large amount of water was needed to feed them, and it was not an easy task for family collecting water from distance sources. Therefore, it became important for them to dig a pokhari/pond close to their house, where their domestic animals could drink directly from the pond. During the dry season especially during the summer, the water springs get dry and access of water become a problem in the past. The monuments in this area are to serve small peasants who have some buffaloes, cows, sheep and goats. The family shrines came to exist as a farm shrine, following the permanent settlement and crop cultivation. These shrines are associated with the spiritual beings of the area. These farm shrines also represent the transition of land from the uncultivated to the cultivated and even cultural land.

In the cosmic imagination they care about the land and provide the availability of resources. People desire to go to heaven after life to enjoy all kinds of happiness. On the other hand, building monuments is the virtuous way to gain access to heaven. Monuments are built in sacred places to receive blessings from as many people as possible. They are associated with water, the most basic element for any living being and most sacred items making a gift, to the living beings and the gods and goddesses. The monument like pokharis and kuwas are associated with the gift of water (Khattri, 1999).

The temples or shrines are built in places where the spiritual beings are supposed to have lived. Most of the time spirits live near the water springs and they travel in a specific linear direction. Some monuments are established in a linear direction. The shamanic tradition of the people in Argal is practiced by all ethnic/caste groups. The shamanic shrines are in most cases family shrines which are established on their farmland. Most of the village temples do not belong to the shamanic tradition. Some scholars argue that temples of Hindu Goddesses belong to the high tradition and the shamanic deities belong to the little tradition in Nepal. In general, the village shrines are public monuments as they are built at the center of the village.

As I have mentioned above, chautaries are built where people needed a comfortable resting place while they are carrying loads or walking up and down steep hills. Pokharies are dug where it is possible to collect drinking water for cattle /buffaloes. The roads and bridges are built where people have difficulties crossing a river or a stream. There is no any specific pattern of selecting a place to construct a road or build a bridge, but the path has to be accessible according to resource or pilgrims. It is hard to find a specific pattern in which particular types of monuments are built. However, most of the monuments like family shrines, pokharis and even some communal shrines are built close to the source water.

As I have mentioned above, the religious houses are built at sacred places. Some of the houses are built on the way to the sacred place. The trend of building monumental houses is declining at present. The increasing commercialization of society marks the proliferation of the hotels, guest houses, and restaurants. Building chautari and pokhari is still in practice, continuity the traditional subsistence types of agriculture. Many chautaris and pokharis are destroyed while constructing jeep road in Rijalchock of Bihun to Argal, Tara and Hila VDC. They have no plan to rebuild them. The shrines are still in care, they are mostly kept for their religious practice and are linked to fertility of crops, livestock, and family members. 


\section{4 | Man Bahadur Khattri}

In Argal, a religious house is called daramsala also known as panto. Panto served various purposes for the Argali people. It was "public space" used as a meeting place of village council to make important decisions on use and management of resources provide justice to the village folk. It was also used as a guest house for government authority when they visit Argal. It was used for public gatherings during ritual, for instance marriage. It was the house for young people as a place for gathering during the night, to sing songs and dance. It also served to the young people to sleep, which was known as bas ghar. Now this religious house is broken, there is nothing left as building, but the place is known as dharamsala. Some old people in Argal wanted to rebuild it, but the house will not be able to serve people as in the past. If it is rebuilt it will commemorate their ancestors, due to changes in the socio-economic conditions of the people.

Now, almost every household has got facility of regular drinking water supply in the village. The water supply was sponsored by a NGO and VDC. They have started to put the sponsored name on the tap. The use of the ponds/kuwa is in a critical situation. Many of the monumental ponds are going to drying. Taking care of the monuments is the responsibility of the builders. Some ponds have already filled with silt, sand and mud, but some are going to be dried. In the same way, some of springs of water are also going to be dry up if they are not taken care of.

\subsection{Ritual and Monument}

Ritual is a social and religious act. Rituals are common feature of Argali people. In Argal, ritual for monuments is seen as a supplementary action to those who build monuments. Ritual involves a flow of gifts and social gathering of kin and relatives. Not only own kin and relatives but also neighbors of various ethnic and caste group. Rituals are performed to avoid unforeseen danger. A new born baby, a newly married couple, a newly built house and the newly built monuments are also ritualized. The Argali Magars sacrifice a male buffalo to ritualize a newly built house. The blood of the victim is sprinkled everywhere, in the belief that every new born beings needs food and drink (Khattri,1999).

Let me recapitulate the ritual for chautaris and pokharies. This ritual is performed in the house and at the spot where the monuments are built. Most importantly, it involves a social gathering of kin, friends, and neighbors. The fasting of the builder is also important. They use ritual objects, ritual food, flowers, and fire. The ritual at the spot of the monuments involves similar actions and events. The important difference is the use of pillars. Two pillars are placed on the chautari and one pillar is installed at the center of the pokhari. In the pokhari the copper pot is placed at the center, where the pillar is placed. The offered material at the pokhari is an indication of the ritual performed.

\section{Ethnicity and National Integrity}

Many scholars and political parties in Nepal are trying to establish Nepal as a multi nation-state. Gurung (2063 B.S.) argues that Nepal is a multi ethnic country but among different ethnic group no multi-national feeling rather they have developed mono-national feeing (2063:370). In the context of federal system on the basis of ethnic/linguistic in Nepal, Harka Gurung (1997) argues that it is fraught with problems of area demarcation and the sustainability of Nepal as a nation. While large-scale inter-regional migration of people has eroded discrete cultural areas, a federal structure could encourage centrifugal forces. He insisted that need of Nepal is the decentralization ultimately leading to the devolution of power (1997:529). Ethnic identities are also associated with territories because ethnic group distinction is also typically rooted in territorial notions of common culture, race or ancestry (Murphy, 1989:411). This is the major 
argument submitted by indigenous people's right activists. It has a wider implication to Nepal's demographic situation as Murphy has said, "dominant groups can and do make ruthless use of power to eviscerate ethnic minorities” (1989:417). So far ethnic movement in Nepal is relatively peaceful but it may not continue for longer period of time. This might turn to violent conflict that might lead to civil war, separatist movement or to the replacement, or displacement or expulsion (Bhattachan, 1998:117). Nepal Federation of Indigenous Nationalities (NEFIN) is working for ethnic autonomy on the basis of the principle of right to selfdetermination (NEFIN 2008). Social scientists particularly social anthropologists use caste as the basis of analysis of social structure in Nepal. Caste in not a multi-dimensional concept still it is linked to identity, which can not determine every aspect of an individual in Nepali society. At the same time it is very sad to state that there is no particular focus on caste and ethnic group from class perspective. It is colonial legacy of South Asia, which is guided by "divide and rule", principle as well as a device to denounce class struggle in the society.

In social anthropology, "ethnicity" is a term that has been used to describe the nature of social interaction between different human groups. By the 1970s it gained popular usage in anthropological literature partly in response to the political situation in the world: increased migration, growth of multicultural societies, and the assertion of different identities (Microsoft Encarta, 2007) and partly to distinguish a particular group from another. Major basis of distinctions are language, race, religion, and color; as these markers become the basis of political identity and claims to a specific role in the political process or power. Thus, ethnic distinctions are transformed into ethnicity (Ghai, 2008:4). It is also liked to identity revitalization and they are associated with other concepts as nativism, nationalism, millenarianism, and liberation (Stein, 1975:276). The government of Nepal has identified and recognized 59 ethnic groups; however Census has reported that there are 101 different caste and ethnic group in Nepal (CBS, 2001). The racial division ethnic groups of Nepal include people of Mongolian, Dravidian, and Proto-Austroid indigenous nationalities (Adibasi janajati), with their own distinct languages, different cultures, historical territories and their existence prior to the formation of modern state (Tamang et. al, 2006). Ethnicity, based on the Greek term ethnos, is frequently distinguished from race, although ethnic groups may share racial characteristics. However, there may exist different ethnic groups within the same race. Attachment to ethnicity, as distinct from attachment to race, may arise in several different ways. First, culturally patterned forms of behavior by which individuals satisfy their needs may bring them closer to some people rather than others. Second, the similarities between members of an ethnic group may be based on physical characteristics as much as cultural characteristics, to create a "consciousness of kind”. Third, similarity of cultural behavior may be seen as a sign of cultural relatedness (Microsoft Encarta, 2007). The total population of ethnic groups in Nepal is 8,272,551 (36.4\%) (Gurung et al., 2006: 4). Majority of people who are categorized as ethnic group are the Mongolian, the Dravidians (41764, 0.180\%) and Proto-Austroid (42698, $0.184 \%$ ) (Gurung et al. 2006). Despite high diversity of ethnic/caste group only six caste/ethnic groups (Chettri, Bahun, Magar, Tharu, Tamang and Newar) have a population exceeding one million. Twenty-five ethnic and caste group have a population between 100,000; 1,000,000 and 17 groups between 50,000 and 100,000 . Similarly 25 groups have 10,000 to 50,000 and 23 between 1,000 and 10,000. Four 
ethnic groups (Munda, Raute, Hyolmo and Kusunda) number less than 661 persons. Among the 31 large groups exceeding a population of 100,000 castes are 21, ethnic 9 and 1 religious group (Gurung et al, 2006:2).

\section{Conclusion}

The multi-ethnic society of Argal helps us to understand the inter ethnic/caste relationship and identity formation. There is no significant conflict among them for utilization of common resources for public purpose, not even for their maintenance. People have realized common benefits from locally built monuments and they have deep respect of local tradition. Cooperation among different monument builders has been sustained without prejudices of any ethnic caste identity. Local autonomy is the best way to solve socio-economic and power problem which so far was dominated by the centralized feudal socio-economic and political system. This also helps to learn development from local level as well as integration of different socioeconomic relationships in society. Present conflict in Nepal is rooted in gaining political as well as economic power. The local monumentality, however, form cultural capital and is linked to economic as well as political status. If we try to establish forcefully ethnic/caste dimension of socio-economic sphere in Nepal, it will certainly destroy harmony of multi-ethnic society and also national integration as a whole.

\section{Reference}

Bhattachan, K.B. (1998). Making No Heads or Tails of the Ethnic "Conundrum" by the

Scholars with European Head and Nepalese Tail in Contribution to Nepalese Studies, Vol. 25, No. 1 (January 1998) PP 111-130. Kathmandu: CNAS/TU

Bradley, R. (1991). Monuments and Places: In Sacred and Profane. Proceedings of a Conference on Archaeology, Ritual and
Religion Oxford, 1989. P. Garwood,D. Jennings, R. Skeates and J. Toms (eds.). Oxford University Committee for Archaeology Monograph No. 32

Bradley, R. (1993). Altering the Earth: The Origins of Monuments in Britain and Continental Europe. The Rhind Lectures 1991-92. Edinburg: Society of Antiquaries of Scotland Monograph Series no. 8 .

CBS (Central Bureau of Statistics) (2002). Population of Nepal: Village Development Committees/Municipalities, Population Census 2001- Selected tables on Caste/Ethnicity, Mother Tongue and Religion (Western Development Region). Kathmandu: CBS Nepal.

CBS 2003

Clarke, C. B. (1874). The Stone Monuments of the Khasi Hills. The Journal of the Anthropological Institute of Great Britain and Ireland, Vol. 3. (1874), PP 481-493. Royal Anthropological Institute of Great Britain and Ireland.

Cooney, G. (1994). Sacred and Secular Neolithic Landscape in Ireland In Sacred Sites, Sacred Places. David L. Carmichael, Jane Hubert, Brian Reeves and Audhild Schanche (eds.). London: One World Archaeology.

Elliott, Cecil D (1964) Monuments and Monumentality. Journal of Architectural Education (1947-1974), Vol. 18, No. 4. (Mar., 1964), pp. 51-53. Association of Collegiate Schools of Architecture

Ghai, Yash (2008). Autonomy and Ethnicity, Negotiating Competing Claims in Multi-ethnic States. New Delhi: Cambridge University Press

Gurung, Harka (1997). State and Society in Nepal. In Nationalism and Ethnicity in a Hindu Kingdom: The Politics of Culture in Contemporary Nepal. Edited by David N. Gellner, Johana PfaffCzarnecka, \& John Whelpton. Amsterdam: Harwood Academic Publishers. 


\section{0 | Man Bahadur Khattri}

Gurung, Harka, Yogendra Gurung and Chhabi Lal Chidi (2006). Nepal Atlas of Ethnic and Caste Groups. Kathmandu: National Foundation for Development of Indigenous Nationalities.

Gurung, Om (2063(BS)). Nepalma Janajati Samasya ra Soyatta Sasanko Prasna (P 359-374) (in Nepali) (The question of Autonomy and Ethnic problem in Nepal). In Nepalko sandarbhama Rajyako Punarsamrachana, edited by Sita Ram Tamang Kathmandu, Nepal.

Harvey, David C. (2003). 'National' Identities and the Politics of Ancient Heritage: Continuity and Change at Ancient Monuments in Britain and Ireland, c.1675-1850. Royal Geographical Society $\mathrm{Vol}$

Khattri, M. B. (1995). Adaptive Systems of the Magar People: An Ethno-ecological Case Study of Argal VDC of Baglung District. A Dissertation Submitted to the Central Department of Sociology/Anthropology Partial Fulfillment of the requirements for the Degree of Masters of Arts in Anthropology. Kathmandu: Tribhuvan University.

1999, sacrificial Places: An Ethnoarchaeological Study of the Ritual Landscape from Argal VDC, Western Nepal. A Thesis Submitted to the Department of Archaeology Partial Fulfillment of the requirements for the Degree of Masters of Philosophy in Archaeology. Bergen: University of Bergen, Norway.

Lahiri, N. (1996). Archaeological Landscapes and Textual Images: A study of the Sacred Geography of Mediaval Ballabgarh. In World Archaeology: Sacred Geography. Richard Bradley (ed.) Vol. 28 No. 2 Oct. London: Routledge.

Microsoft @ Encarta ${ }^{\circledR} \quad 2007$. (C) 1993-2006 Microsoft Corporation. All rights reserved.

Murphy, A. B. (1989) Territorial Policies in Multiethnic States. Geographic Review, Vol 79 No. 4 (Oct 1989) pp 410-421 